DOI: $\underline{10.20472 / E S .2019 .8 .1 .009}$

\title{
EFFECT OF NAFTA ON MEXICO'S WAGE INEQUALITY
}

\section{MARTHA RODRIGUEZ-VILLALOBOS, ANTONIO JULIÁN-ARIAS, ALEJANDRO CRUZ-MONTAÑO}

\begin{abstract}
:
One of the benefits that the signing of the North American Free Trade Agreement (NAFTA) would bring to the country was the reduction of large differences in wages as a result of the increase in productivity. The present study measures the effect of demographic, labor, and sector variables on Mexico's wage inequality during the period 1988 to 2017, as well as the impact that the incorporation to NAFTA has had. Through a fixed effects model, it was found that the increase in the proportion of people working in the service and agricultural sectors increased the wage gap, as well as the people who occupy managerial positions, since they obtained a relative salary higher than the average. Despite the expected results of NAFTA, this economic trade integration increased the wage differential in Mexico and these levels are invariant over time, giving way to proposals to change the minimum wage.
\end{abstract}

\section{Keywords:}

wage inequality; income distribution; occupational analysis; sectorial analysis; NAFTA; fixed effects

JEL Classification: F13, J31, O15

\section{Authors:}

MARTHA RODRIGUEZ-VILLALOBOS, Universidad de Monterrey, Mexico, Email: martha.rodriguezv@udem.edu

ANTONIO JULIÁN-ARIAS, Universidad de Monterrey, Mexico, Email: jose.julian@udem.edu ALEJANDRO CRUZ-MONTAÑO, Universidad de Monterrey, Mexico, Email: adrian.cruzm@udem.edu

\section{Citation:}

MARTHA RODRIGUEZ-VILLALOBOS, ANTONIO JULIÁN-ARIAS, ALEJANDRO CRUZ-MONTAÑO (2019). Effect of NAFTA on Mexico's wage inequality. International Journal of Economic Sciences, Vol. VIII(1), pp. 131-149., 10.20472/ES.2019.8.1.009 


\section{Introduction}

Inequality within a country is a phenomenon widely studied in three areas: the unequal distribution of wealth, disparities in the conditions of life of different population groups, and the gap between the salaries of workers. Currently, at a global scale, an important gap exists between the salaries of the poorest and richest population, where the wealth of 62 multimillionaires equals the wealth of half of the entire population (Elliot, 2016). Mexico is situated inside the $25 \%$ of countries that have the highest levels of inequality (Frederick, 2016); to diminish this gap, objectives have been proposed in its development policies and government programs have been created; even during the initial process of commercial liberalization in 1994, with the dawn of the North American Free Trade Agreement (NAFTA), an increase in workforce productivity that would help diminish this wage inequality was expected. Even though this didn't happen in certain sectors, as was the case with manufacturing where data indicates that from 1993 onward, labor supply in this sector increased, diminishing the salary of workers in this sector (Messmacher, 2000), countrywide evidence has pointed out that the level of wage inequality in Mexico started to diminish from the implementation of NAFTA in 1994, at least until 2010 (Campos-Vázquez, 2013).

The objective of the present investigation is to measure the impact that demographic, labor, and sector variables have on the wage inequality of Mexico in the period 1988 to 2017, as well as the effect that NAFTA has had on the wage gap. Finally, the effects of demographic, labor, and sector variables before and after NAFTA will be compared.

The following graph shows the levels of average wage inequality, measured as the differential between the logarithm of the average wages of the $90^{\text {th }}$ and $10^{\text {th }}$ percentiles, of 15 of the main entities in Mexico starting from the presidency of Carlos Salinas de Gortari, whose government carried out the 1998 financial reform that established the basis of a financial system that corresponded to the Mexican market's globalization tendencies prior to NAFTA's adoption. 


\section{Graph 1. Wage inequality by federal entity, 1988-2017}

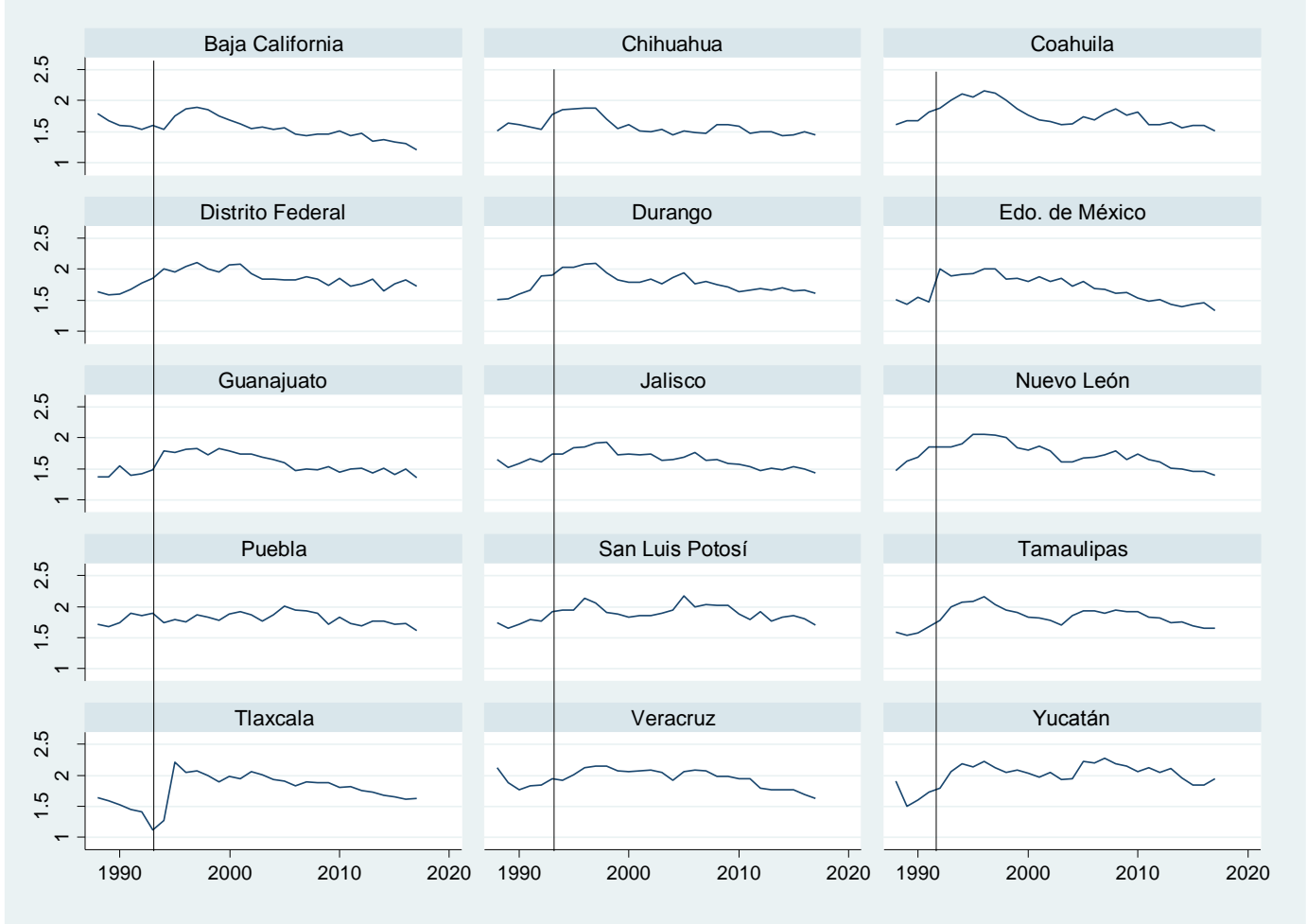

Source: Own elaboration with ENEU-ENOE data 1988-2017

The graph shows that the states that have the highest levels of inequality are Puebla, San Luis Potosí, Tamaulipas, Tlaxcala, Veracruz and Yucatán. In general, an upward trend is observed in wage inequality during the period prior to NAFTA, 1988 to 1993 (except in Baja California, Tlaxcala and Veracruz); after this year, the data indicates an increase in wage inequality in the first years of NAFTA and a slight decrease in the following years. It is important to note that in 2017 , the level of inequality of all entities is similar to that of the 1990s, prior to NAFTA.

To analyze the composition of this wage inequality measurement, the following graph shows the average real wage of the $10^{\text {th }}$ and $90^{\text {th }}$ percentile of the wage distribution, using as a reference the wage found in $50 \%$ of the distribution in each entity and year. 


\section{Graph 2. Real wage by average hour by entity, 1988-2017}

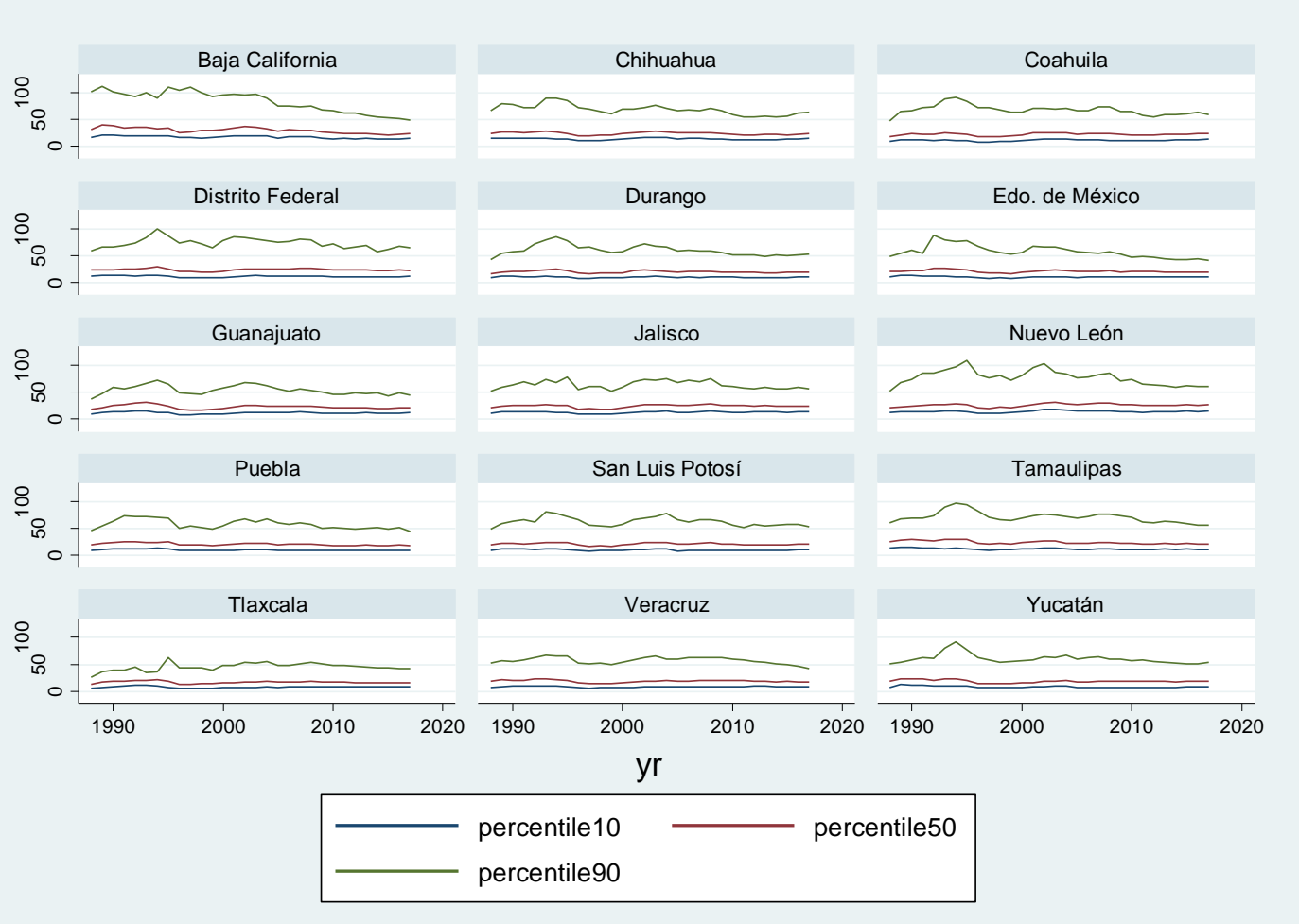

Source: Own elaboration with ENEU-ENOE data 1988-2017

As can be observed, the hourly wage of the $10^{\text {th }}$ percentile in all entities has been maintained practically at the same level, around $\$ 10$, while the wage of the $90^{\text {th }}$ percentile has presented a greater variation. When comparing the wage of 1994 to that of 2017 within the $90^{\text {th }}$ percentile the data shows that Nuevo León, Tamaulipas and Yucatán presented a decrease of more than 64\%, while in Baja California it was around $80 \%$ going from $\$ 90.07$ to $\$ 49.87$.

This investigation is divided in five sections: the next section summarizes the literature review, the third describes the methodology used, the fourth presents the results. Finally, in the last section the conclusions and main findings are presented.

\section{Literature review}

Economic theory establishes that inequality can be measured by means of wealth or the possession of assets and properties, wages, earnings, population structure, and the redistribution of government transfers, with wage being the most used in literature (Todaro and Smith, 2012).

The literature identifies at least three causes for wage inequality: change in demand, change in supply, and institutional changes in the labor market. Within changes in demand, two factors are found as the main elements: the first relates to the increase in inequality with globalization and the greater competition of intensive goods, while the second identifies the relationship between changes in technology and skilled labor demand (Castro and Huesca, 2007). To measure wage inequality, several different indicators can be used such as relative wage disparity between 
qualified workers and non-qualified workers (Krueger, 1993; Juhn, Murphy and Pierce, 1993; Card and DiNardo, 2002), or the distribution between formal and informal workers (Marcouiller, de Castilla and Woodruff, 1997; Krstić and Sanfey, 2011; Kahyalar, et. al., 2018), the relative difference of wages between percentiles (Budría and Moro-Egido, 2008; Dustmann, Ludsteck and Schönberg, 2009; Antonczyk, Fitzenberger, and Sommerfeld, 2010; Tansel and Bodur, 2012), equations of salaries that try to identify variations in the performance of different education groups (Dolton, O'Neill and Sweetman, 1996; Card, 2001; Weichselbaumer and Winter-Ebmer, 2005; Blau and Kahn, 2017), a fixed inequality index like Gini or Thiel's index (Sala-i-Martin, 2006; Islam and Safavi, 2019; Yang and Cao, 2019), and the coefficients of variation (Katz, 1999; Lemieux, 2006), among other measurements that consider wellbeing in the distribution.

Among the research with the greatest relevance in Mexico's wage inequality one can point to Castro and Huesca (2007) who perform a literature review about the labor market and the problems of wage inequality. The authors find a consensus during the second half of the 1980's: Mexico presented growth in wage disparity, where the characteristic element was a greater rate of education levels and training caused by changes in demand (commerce and technological change), fluctuations in supply and institutional changes; meanwhile, in the first half of the 1990's, there was a decrease in wage inequality, but only due to relative changes in the returns to education. In general, the authors found that in the studies included in their research, commercial liberalization was a catalyst in the process of technological change, through the cheapening of capital goods, foreign investment and the ease of exports and imports of inputs.

Considering these two same decades, Meza (1999) utilized microdata from 16 urban zones of the National Survey of Urban Employment (ENEU, as per its Spanish acronym) during the period of 1988-1993 to analyze the decomposition of wage through four measures of inequality: the differentials of the $75-25,90-10,90-50$, and 50-10 percentiles. Among the results found, it was detected that the quantity of qualified workers explains the existing wage differential between the $90^{\text {th }}$ and $10^{\text {th }}$ percentiles, where the $90^{\text {th }}$ percentile obtained in absolute terms an hourly wage 2 to 9 times greater than the $10^{\text {th }}$ percentile. Later, Meza (2005) expanded the period analyzed to 1999. The author found, through a regression of weighted ordinary least squares, a positive relation between investment in higher education and inequality in the lower part of the wage distribution. The author concludes that wage inequality is explained by changes in occupational structures of businesses and by biased technological change.

A study by Campos-Vázquez (2013) utilized data from the National Household Income and Expenditure Survey (ENIGH, as per its Spanish acronym) to analyze the variations in wage inequality and its relation to work experience returns caused by NAFTA in the upper part of the wage distribution in the period of 1996-2006. Using a decomposition analysis of relative wages, the author found that wage inequality was reduced in 15\% starting from 1994 onwards due to the increment in the relative supply of qualified workers that NAFTA caused. Being that the wage structure is defined in great measure by the supply and demand of workers with different education and experience levels, what he found was that labor demand by education level was defined in great measure by international commerce and by the characteristics of technological change. The author found that the effect that commercial liberalization had over wage inequality in Mexico was opposite to what the standard trade model assumes, since instead of reducing the rate of qualified wages with respect to non-qualified wages, in Mexico due to the relative abundance of this type of work with respect to the United States, this ratio increased. Theory 
indicates that the policies of trade liberalization should diminish inequality in developing countries and change the wage structure of industrialized nations.

Another recent study that measures inequality but considers the period of 1989 to 2010 is carried out by Campos, Esquivel and Lustig (2014), where the ENIGH was used and they applied the recentered influence function to decompose the changes of wages per hour into its characteristics and yields. The authors corroborated the results obtained by previously named authors: inequality increased in the period of 1989 to 1994, diminished between 1994 and 2006, and presented a slight increase during the period of 2006 to 2010. They also found that in Mexico the rates of return of hourly wages for workers with secondary, upper-secondary, and higher education present a direct relation to wage inequality.

The present study analyzes the effect that NAFTA has had on Mexico's inequality of the 15 most representative entities of Mexico in the period 1988 to 2017 and measures the incidence of different factors that determine it. While this study includes only 15 entities (due to the availability of the data), the rest of them would be expected to present wage inequality levels no greater than these entities, so the results could be considered as representative of the entire country. The theory of comparative advantages of international trade sustains that with free trade, nations will specialize and export those goods and services in which a comparative advantage exists in respect to other nations, and will import goods and services in which they present disadvantages (Kilic, 2002); for the case of Mexico, a country with abundant unskilled labor with respect to the United States, it would be expected that as a result of the entry to NAFTA this relative advantage would increase the demand of this type of work, generating an increase in its salary and diminishing wealth inequality, in addition to generating a relative improvement in the price of intensive goods in unskilled labor.

\section{Methodology}

\subsection{Data and sample}

This investigation defines inequality as the relative difference between the logarithm of the average wages of the $90^{\text {th }}$ and $10^{\text {th }}$ percentiles. The $90^{\text {th }}$ percentile was considered since it was the measure of wage distribution that presented the most relevant change in average real wage during the analyzed period, whereby it will be considered as the upper part of the wage distribution. The model proposed by Meza (1999) was used as a reference, which considers the effect that economic cycles, and changes in population, occupational and sectorial structures have on the 15 most representative metropolitan areas of the country in terms of wage inequality. Data from the National Survey of Urban Employment (ENEU) for the period 1988-2004, and from the National Survey of Occupation and Employment (ENOE) for the period 2005-2017, both surveys carried out by the National Institute of Statistics and Geography (INEGI, as per its Spanish acronym) were used. The ENEU is a trimestral survey that compiles sociodemographic, labor and wage information of 15 metropolitan areas ${ }^{1}$, which are considered the wage markets of the country at a state level. There are three distinct revisions of the basic questionnaire of these

\footnotetext{
1 The states of Baja California, Coahuila de Zaragoza, Chihuahua, Distrito Federal, Durango, Guanajuato, Jalisco, Estado de México, Nuevo León, Puebla, San Luis Potosí, Tamaulipas, Tlaxcala, Veracruz de Ignacio de la Llave and Yucatán.
} 
two surveys: $1987-1994{ }^{1}, 1995-1999$, and 2000-2004. It is worth mentioning that the ENOE obtains the same information as the ENEU, and although it already considers all the federal entities, in this study only the same 15 entities will be considered. The sample was made up of men and women of working age (15 to 65 years) ${ }^{3}$ and the information related to their main employment was considered. Unpaid workers were not considered as they did not have salary information.

As mentioned before, the model considers the change in sector structures, for which the three most important sectors in Mexico were included: the service sector, which in addition to representing on average about two thirds of Gross Domestic Product (GDP), captures the greatest proportion of economic output; the manufacturing sector, which represents almost a fifth of GDP with a strong concentration in the north and center of the country, and the agricultural sector, where a fifth of the Mexican population works; regarding the population structure, the variables taken into account were the proportion of people with completed higher education, the proportion of people that have no studies, the proportion of people of age entering the labor market (15 to 25 years) and the proportion of people of age to exit the labor market (56 to 65 years); in the occupational structure, the considered variables were the proportion of people with managerial positions and the proportion of people with assistant positions. Finally, a neighborhood variable was included to control the ordinary effects of the economic cycle through the level of unemployment of each entity in each quarter.

Table 1 contains the descriptive statistics of the wage sample. The periods 1988-1993 and 19942017 were used as a reference to observe the changes in real wage before and after NAFTA's signing.

\footnotetext{
11987 was not considered since it is not compatible with the rest; this is due to a difference in the variables used to measure hourly wage in this year.

${ }^{3}$ The Political Constitution of the United Mexican States, article 123, sub-index III, and the Federal Labor Law, article 22, set the minimum working age to 15 years (Official Gazette of the Federation: 06/17/2014), but there is no law that sets a maximum. However, in the Income Tax Law (ISR), article 142, sub-index XVIII, and in the Social Security Law of the Mexican Institute of Social Security (IMSS), article 162, the retirement age is set to 65 years.
} 
Table 1. Distribution of real salary by entity in 1988-1993 and 1994-2017

\begin{tabular}{|c|c|c|c|c|c|c|}
\hline Federal Entity & Year & Mean & $\begin{array}{c}T \text { test } \\
\text { (Mean) }\end{array}$ & $\begin{array}{l}\text { Standard } \\
\text { Deviation }\end{array}$ & $\begin{array}{c}\text { Percentile } \\
90\end{array}$ & $\begin{array}{c}\text { Percentile } \\
10\end{array}$ \\
\hline \multirow[t]{2}{*}{ Baja California } & $1988-1993$ & 54.79 & * & 75.47 & 100.67 & 19.91 \\
\hline & $1994-2017$ & 41.25 & & 51.02 & 86.65 & 17.16 \\
\hline \multirow[t]{2}{*}{ Coahuila } & $1988-1993$ & 37.3 & * & 71.03 & 73.59 & 11.76 \\
\hline & $1994-2017$ & 34.47 & & 47.35 & 69.9 & 11.45 \\
\hline \multirow[t]{2}{*}{ Chihuahua } & $1988-1993$ & 43.01 & * & 115.92 & 77.01 & 15.35 \\
\hline & $1994-2017$ & 34.67 & & 78.12 & 68.78 & 13.96 \\
\hline \multirow[t]{2}{*}{ Distrito Federal } & $1988-1993$ & 38.51 & * & 63.12 & 69.56 & 12.89 \\
\hline & $1994-2017$ & 39.91 & & 65.02 & 76.35 & 11.19 \\
\hline \multirow[t]{2}{*}{ Durango } & $1988-1993$ & 33.85 & * & 56.06 & 66.82 & 11.3 \\
\hline & $1994-2017$ & 28.58 & & 44.7 & 62.11 & 9.84 \\
\hline \multirow[t]{2}{*}{ Guanajuato } & 1988-1993 & 32.27 & * & 37.68 & 55.68 & 12.62 \\
\hline & $1994-2017$ & 28.03 & & 34.78 & 57.9 & 10.32 \\
\hline \multirow[t]{2}{*}{ Jalisco } & 1988-1993 & 36.99 & * & 79.33 & 63.24 & 12.45 \\
\hline & $1994-2017$ & 33.39 & & 40.24 & 64.51 & 11.85 \\
\hline \multirow[t]{2}{*}{ Mexico } & $1988-1993$ & 35.83 & * & 88.52 & 71.51 & 12.31 \\
\hline & $1994-2017$ & 28.68 & & 39.86 & 58.25 & 10.03 \\
\hline \multirow[t]{3}{*}{ Nuevo Leon } & $1988-1993$ & 41.12 & * & 66.82 & 74.78 & 13.27 \\
\hline & $1994-2017$ & 41.75 & & 64.84 & 80.12 & 13.6 \\
\hline & t statistic & $-6.18^{*}$ & & & & \\
\hline \multirow[t]{2}{*}{ Puebla } & $1988-1993$ & 34.08 & * & 48.83 & 62.64 & 10.59 \\
\hline & $1994-2017$ & 25.73 & & 48.75 & 56.9 & 9.06 \\
\hline \multirow[t]{2}{*}{ San Luis Potosi } & $1988-1993$ & 33.7 & * & 49.28 & 62.83 & 10.87 \\
\hline & $1994-2017$ & 29.41 & & 42.22 & 63.47 & 9.17 \\
\hline \multirow[t]{2}{*}{ Tamaulipas } & $1988-1993$ & 38.49 & * & 54.07 & 71.27 & 13.14 \\
\hline & $1994-2017$ & 35.28 & & 56.3 & 73.2 & 11.24 \\
\hline \multirow[t]{2}{*}{ Tlaxcala } & $1988-1993$ & 22.88 & & 55.68 & 37.05 & 8.15 \\
\hline & 1994-2017 & 23.83 & & 30.23 & 47.88 & 7.25 \\
\hline \multirow[t]{2}{*}{ Veracruz } & 1988-1993 & 32.3 & * & 76.1 & 59.27 & 9.19 \\
\hline & 1994-2017 & 25.74 & & 48.54 & 58.25 & 7.62 \\
\hline \multirow[t]{2}{*}{ Yucatan } & 1988-1993 & 31.68 & * & 39.7 & 59.63 & 10.77 \\
\hline & 1994-2017 & 27.97 & & 41.71 & 59.7 & 7.64 \\
\hline
\end{tabular}

Source: Own elaboration with ENEU-ENOE data 1988-2017

* Indicates significance at the 5 percent level 
The data indicates that the average wage before NAFTA is greater than the wage after it in all entities except for Mexico City, Nuevo León and Tlaxcala. The means tests performed for each entity were all significant except for Tlaxcala, which indicates that all entities presented a statistical difference in their real wage before and after NAFTA. Regarding the dispersion of wages, the data shows that Chihuahua is the state with the greatest dispersion in both periods.

When analyzing the $10^{\text {th }}$ and $90^{\text {th }}$ percentiles, it is observed that Baja California has the highest average real hourly wage in the period prior to NAFTA with $\$ 100.67$, which represents 12 times the wage of Tlaxcala $(\$ 8.15)$. This same comparison in the period after NAFTA shows that the average wage of Baja California in the $90^{\text {th }}$ percentile $(\$ 86.65)$ is equivalent to 11.9 times that of Tlaxcala in the $10^{\text {th }}$ percentile $(\$ 7.25)$. In summary, a slight decrease of the wage differential is observed: before NAFTA the $90^{\text {th }}$ percentile was 12.34 times greater than the $10^{\text {th }}$ percentile, while after it's signing it was 11.9 times greater.

When analyzing the $10^{\text {th }}$ and $90^{\text {th }}$ percentiles, it is observed that Tlaxcala has the lowest average real hourly wage in the period prior to NAFTA with $\$ 8.15$, which represents 12 times the highest average wage which belongs to Baja California (\$100.67).

\subsection{Models}

To measure the effect that changes in population, occupation, and sector structures have on wage inequality, the following Ordinary Least Squares (OLS) model was estimated for the 15 most representative Mexican entities during the period of 1988 to 2017 represented in equation 1:

$\log \left[\frac{w_{a k}}{w_{b k}}\right]=\alpha+\beta_{1} e 1525_{k}+\beta_{2} e 5665_{k}+\beta_{3}$ without $_{k}+\beta_{4}$ higher $_{k}+\beta_{5}$ agr $_{k}+\beta_{6}$ manuf $_{k}+$ $\beta_{7} \operatorname{serv}_{k}+\beta_{8}$ managers $_{k}+\beta_{9}$ manual $_{k}+\beta_{10}$ unemp $_{k}+\beta_{11}$ NAFTA $+\varepsilon_{k}$

where $\log \left[w_{a k} / w_{b k}\right]$ is the measurement of wage inequality calculated as the difference between the logarithm of average real wage of the $90^{\text {th }}$ percentile (represented by $a$ ) and the logarithm of average real wage of the $10^{\text {th }}$ percentile (represented by $b$ ) of the wage distribution; $k$ indicates the entity; to measure the change in population structure the following variables were considered: $e 1525_{k}$ is the proportion of people between 15 to 25 years of age with respect to the working age population; $e 5665_{k}$ is the proportion of people between 56 and 65 years with respect to the working age population; without $_{k}$ is the proportion of the population that does not have studies with respect to the working age population; higher $_{k}$ is the proportion of the population that has completed a higher education with respect to the working age population; to measure the changes in the sectorial structure the following variables were considered: $a g r_{k}$ represents the proportion of workers in the agricultural sector with respect to the working age population; manuf $f_{k}$ represents the proportion of workers in the manufacturing sector with respect to the working age population; serv $k_{k}$ represents the proportion of workers in the service sector with respect to the working age population; to measure the change in occupational structure, the following variables were considered: managers $s_{k}$ represents the proportion of people in managerial or executive 
positions with respect to the working age population; manual $k_{k}$ represents the proportion of workers as manual laborers, artisans or assistants with respect to the working age population. The unemp $_{k}$ variable is the rate of unemployment that includes the economic cycles, NAFTA is a dichotomous variable equal to 0 for the years 1988 to 1993 and equal to 1 from 1994 to 2017, and finally, $\varepsilon_{k}$ is the error term that is assumed to have a normal distribution with a mean of 0 .

The following fixed effects model will be estimated to account for the heterogeneity of each entity:

$\log \left[\frac{w_{a, k t}}{w_{b, k t}}\right]=\alpha+\beta_{1} e 1525_{k t}+\beta_{2} e 5665_{k t}+\beta_{3}$ without $_{k t}+\beta_{4}$ higher $_{k t}+\beta_{5}$ agr $_{k t}+\beta_{6}$ manuf $_{k t}+$

$\beta_{7} \operatorname{serv}_{k t}+\beta_{8}$ managers $_{k t}+\beta_{9}$ manual $_{k t}+\beta_{10}$ unemp $_{k t}+\beta_{11}$ NAFTA $+v_{k}+u_{t}$

where subscript $k$ refers to the federal entity and $t$ indicates the year; the error term is decomposed in two parts: $v_{k}$ represents the fixed effect for each entity and $u_{t}$ the random effect. The rest of the variables are defined as in equation 1.

Inequality presents a structural change starting from the implementation of NAFTA, so model 2 will be estimated for each of the periods with the purpose of comparing the change in the coefficients.

In general, it's expected that the sign of variable e1525 be a positive one, given that an increment in the proportion of people entering the labor market represents a greater labor supply, which would decrease wages, and therefore would have an increment in wage inequality. For variable e5665 the contrary is expected given that an increment in the proportion of people exiting the labor market represents the exit of high salaries due to their labor experience, and therefore, a decrease in wage inequality.

For the variables without and manual a positive sign is expected since they represent unskilled workers which receive the lowest salaries in the wage distribution, so that each increment in the unskilled workforce would increase inequality. On the other hand, the variables higher and managers represent the proportion of skilled workers and it is expected they have a positive relation with wage inequality since they receive the highest salaries.

Within the sector variables, manuf would have a positive relation with wage inequality because it captures the wage of a considerable number of unskilled workers laboring in factories and maquiladoras. In an analogous manner for variables agr and serv a positive sign would be expected given the low compensation levels for jobs in these sectors. Variable unemp would be expected to have a positive sign given that it represents the ordinary effects of the economic cycle. For variable NAFTA a negative sign is expected since the data shows a tendency for wage inequality to decrease in the period described by this qualitative variable.

Additionally, it is important to know if inequality among entities is stationary or not to identify if inequality is stable throughout time, so the Fisher unit root test for panel data ${ }^{4}$ will be used, which consists of estimating the following model:

\footnotetext{
${ }^{4}$ This test combines the evidence of the hypothesis for the unit root test of $\mathrm{N}$ tests carried out in $\mathrm{N}$ units in the cross section. In each of the $\mathrm{N}$ tests a Phillips-Perron test is carried out (Maddala and Wu, 1999).
} 


$$
Y_{i, t}=\rho_{i} Y_{i, t-1}+Z_{i, t}^{\prime} \gamma_{i}+\epsilon_{i, t}
$$

where $Y$ is wage inequality and $Z_{i, t}^{\prime}$ represents the matrix with each specific mean of each entity and the linear trend in time. This fixed effects model and tendency was considered since inequality in none of the entities is zero and because the policies to decrease inequality apply to all entities in the same time period.

\section{Results}

With the purpose of comparing the obtained findings, Table 2 shows the results of equations 1 and 2 to explain the 90-10 wage differential of the 15 most representative entities of Mexico during the period 1988-2017. The first column corresponds to the model of Ordinary Least Squares (OLS) while the second to the Fixed Effects model consistent in heteroscedasticity and autocorrelation.

\section{Table 2. Model results}

\begin{tabular}{|c|c|c|}
\hline & OLS & $\begin{array}{l}\text { Fixed effects } \\
\text { (Consistent) }\end{array}$ \\
\hline \multirow[t]{2}{*}{ e1525 } & $1.433^{\star *}$ & $1.916^{\star \star}$ \\
\hline & $(0.539)$ & $(0.832)$ \\
\hline \multirow[t]{2}{*}{ e5665 } & $-2.844^{* *}$ & $-3.639^{* *}$ \\
\hline & $(0.948)$ & $(1.23)$ \\
\hline \multirow[t]{2}{*}{ without } & $2.413^{\star \star}$ & $1.603^{\star *}$ \\
\hline & $(0.272)$ & $(0.499)$ \\
\hline \multirow[t]{2}{*}{ higher } & $1.157^{\star \star}$ & -0.207 \\
\hline & $(0.232)$ & $(0.452)$ \\
\hline \multirow[t]{2}{*}{ agr } & $2.715^{\star *}$ & $2.033^{* *}$ \\
\hline & $(0.373)$ & $(0.613)$ \\
\hline \multirow[t]{2}{*}{ manuf } & -0.688 & $2.383^{\star \star}$ \\
\hline & $(0.419)$ & $(0.858)$ \\
\hline \multirow[t]{2}{*}{ serv } & $1.594^{\star \star}$ & $2.774^{\star \star}$ \\
\hline & $(0.342)$ & $(0.767)$ \\
\hline \multirow[t]{2}{*}{ managers } & 0.151 & -0.922 \\
\hline & $(0.778)$ & $(0.974)$ \\
\hline \multirow[t]{2}{*}{ manual } & $-1.076^{\star \star}$ & $-3.162^{\star \star}$ \\
\hline & $(0.432)$ & $(0.706)$ \\
\hline \multirow[t]{2}{*}{ unemp } & $0.907^{\star}$ & $1.423^{*}$ \\
\hline & $(0.500)$ & $(0.771)$ \\
\hline \multirow[t]{2}{*}{ NAFTA } & $0.110^{\star *}$ & $0.185^{\star \star}$ \\
\hline & $(0.041)$ & $(0.034)$ \\
\hline \multirow[t]{2}{*}{ Constant } & $0.792^{\star *}$ & 0.712 \\
\hline & $(0.272)$ & $(0.485)$ \\
\hline Observations & 450 & 450 \\
\hline Adjusted R-Squared & 0.504 & 0.539 \\
\hline Jarque-Bera test (JB ) & $7.442^{* \star *}$ & \\
\hline Wooldridge test (F) & & $50.665^{* * *}$ \\
\hline Modified Wald test $\left(X^{2}\right)$ & & $120.75^{\star \star \star}$ \\
\hline
\end{tabular}

Source: Own elaboration with ENEU-ENOE data 1988-2017

Note: Standard error in parenthesis

* Indicates significance at the 10 percent level

** Indicates significance at the 5 percent level

*** Indicates significance at the 1 percent level 
When comparing the results, it is observed that the coefficient for the proportion of young people in the labor market increases its magnitude when correcting the bias obtained from the OLS model, so the final effect is of 1.9. As was expected, an increase in the proportion of people that begin their working life increases the wage gap, and an increase in the proportion of people soon to leave the workforce decreases it. Comparing the effect that these two groups have, the results show that the impact that generates an increment in the proportion of people between 56 and 65 years is almost double the one that would be obtained with an increment in the proportion of youths due to their high wage levels.

The effect that generates an increment in the proportion of people without studies was overestimated, staying at 1.6 after correcting the bias; on the other hand, in the case of the variable for the proportion of people that have a higher education in the fixed effects model, it is not a factor that influences wage inequality.

A strong effect is observed in the sectors considered, that is, agriculture, manufacture and service, where an increment in the proportion of people in these sectors would increase wage inequality if the whole period analyzed from 1988 to 2017 is considered.

The dichotomic variable NAFTA has a direct relation to wage inequality, which means that starting from 1994, the wage inequality of the 15 entities increased in 0.185 , or in other words, the highest percentile in the distribution represents 1.2 times the lowest percentile. This result contrasts the one obtained with OLS where the effect of NAFTA over inequality was underestimated.

Once the variables that have an impact on wage inequality have been determined, Table 3 shows the results of equation 2, where the impact that these variables have in each period is compared, with the purpose of seeing the change that has been generated after entering NAFTA. The first column corresponds to the period of 1988 to 1993, and the second column to the period of 1994 to 2017. In both cases the Fixed Effects model is consistent in heteroscedasticity and autocorrelation.

In the regression that considered the years after NAFTA, the determination coefficient shows that a $65.2 \%$ variability in the $90-10$ wage differential is explained with the independent variables, compared to a $49.8 \%$ value for the years prior to NAFTA, which indicates that the considered variables have taken on greater relevance in the former.

When comparing the results, it is observed that the proportion of young people coefficient (e1525) is positive in the period after NAFTA, since an increase in this variable, given the population dynamics of the country where there are more and more young people to contribute towards increase inequality, which indicates that the relative wages of this group are lower when compared to other age groups, as is the case for people soon to retire, where evidently their salary is greater, which decreases the wage gap. 
Table 3. Fixed effects model results, by period

\begin{tabular}{|c|c|c|}
\hline \multirow{2}{*}{ Variable } & \multicolumn{2}{|c|}{ Coefficient } \\
\hline & Before NAFTA & After NAFTA \\
\hline \multirow[t]{2}{*}{ e1525 } & $-3.786^{\star \star}$ & $3.867^{\star \star}$ \\
\hline & (1.738) & $(0.827)$ \\
\hline \multirow[t]{2}{*}{ e5665 } & -0.536 & $-2.031^{*}$ \\
\hline & (2.925) & (1.049) \\
\hline \multirow[t]{2}{*}{ without } & -0.859 & 0.979 \\
\hline & $(1.423)$ & $(0.586)$ \\
\hline \multirow[t]{2}{*}{ higher } & -0.74 & 0.509 \\
\hline & (2.128) & $(0.351)$ \\
\hline \multirow[t]{2}{*}{ agr } & $7.226^{\star \star}$ & $3.058^{* *}$ \\
\hline & $(2.383)$ & $(0.622)$ \\
\hline \multirow[t]{2}{*}{ manuf } & 2.604 & 1.161 \\
\hline & $(1.774)$ & $(1.281)$ \\
\hline \multirow[t]{2}{*}{ serv } & $7.489^{* *}$ & $2.023^{* *}$ \\
\hline & $(1.447)$ & $(0.547)$ \\
\hline \multirow[t]{2}{*}{ managers } & -0.391 & $4.516^{\star \star}$ \\
\hline & $(0.985)$ & $(1.357)$ \\
\hline \multirow[t]{2}{*}{ manual } & -0.929 & 0.499 \\
\hline & (1.644) & $(1.213)$ \\
\hline \multirow[t]{2}{*}{ unemp } & $2.487^{* *}$ & $2.196^{* *}$ \\
\hline & $(1.119)$ & $(0.652)$ \\
\hline \multirow[t]{2}{*}{ constant } & $1.790^{\star \star}$ & -0.473 \\
\hline & $(0.817)$ & $(0.438)$ \\
\hline Observations & 90 & 360 \\
\hline Adjusted R-squared & 0.498 & 0.652 \\
\hline Wooldridge test $F(1,14)$ & $6.360^{* *}$ & $66.625^{\star \star \star}$ \\
\hline Modified Wald test $X^{2}(15)$ & $297.70^{\star \star \star}$ & $54.45^{\star \star \star}$ \\
\hline
\end{tabular}

Source: Own elaboration with ENEU-ENOE data 1988-2017

Note: Standard error in parenthesis

* Indicates significance at the 10 percent level

** Indicates significance at the 5 percent level

*** Indicates significance at the 1 percent level

The results indicate that the labor market does not reward a greater investment in human capital with greater wages in relative terms, nor the opposite case, that is, when people do not have an education, or in other words, the education level is not a factor that influences wage inequality. Regarding the type of occupation, the variable that represents the proportion of workers with management positions apparently was not determinant to wage inequality before 1994, but starting from NAFTA onwards it is the variable with the greatest magnitude (4.5) indicating that the occupational adjustment that was generated after this commercial treaty meant greater salaries with relation to other occupations, increasing the wage gap.

The sectorial variables used in this investigation present different results before and after NAFTA. The proportion of jobs in manufacturing is not significant in neither of the periods, an opposite in Table 2, where this variable directly contributed to wage inequality. In the case of the agricultural sector variable, the magnitude of the coefficient is reduced after the structural change: before 1994 , for each increment of $1 \%$ in the proportion of jobs in the agricultural sector, wage inequality increases in 7.22 (the upper percentile is 1,366 times greater than the lower percentile), after the 
entry into force of NAFTA this incidence is reduced to 3.06 (only 21 times greater); on the other hand, the services sector variable indicates that although the relative wages in this sector are still greater, the wage level has decreased.

Once the results show that the effects which increase inequality the most after NAFTA are the proportion of people that work in management positions and the proportion of people that work in the agricultural and services sectors, two graphs are presented to explain their effect on the inequality level.

Graph 3 shows the average real wage of the people with managerial positions and the average wage of the entity. It is observed that in all states, in the period prior to NAFTA the average wage for the people with managerial positions is like the one obtained by the average wage of the entity, but starting from 1994, the wage of the people with managerial positions increases due to biased technological changes towards these occupations (Meza, 2005). It is observed that the states where the greatest salaries are obtained are Tamaulipas and Yucatán, states which according to Graph 1 presented the highest levels of inequality.

\section{Graph 3. Average real wage per hour for managers by entity}

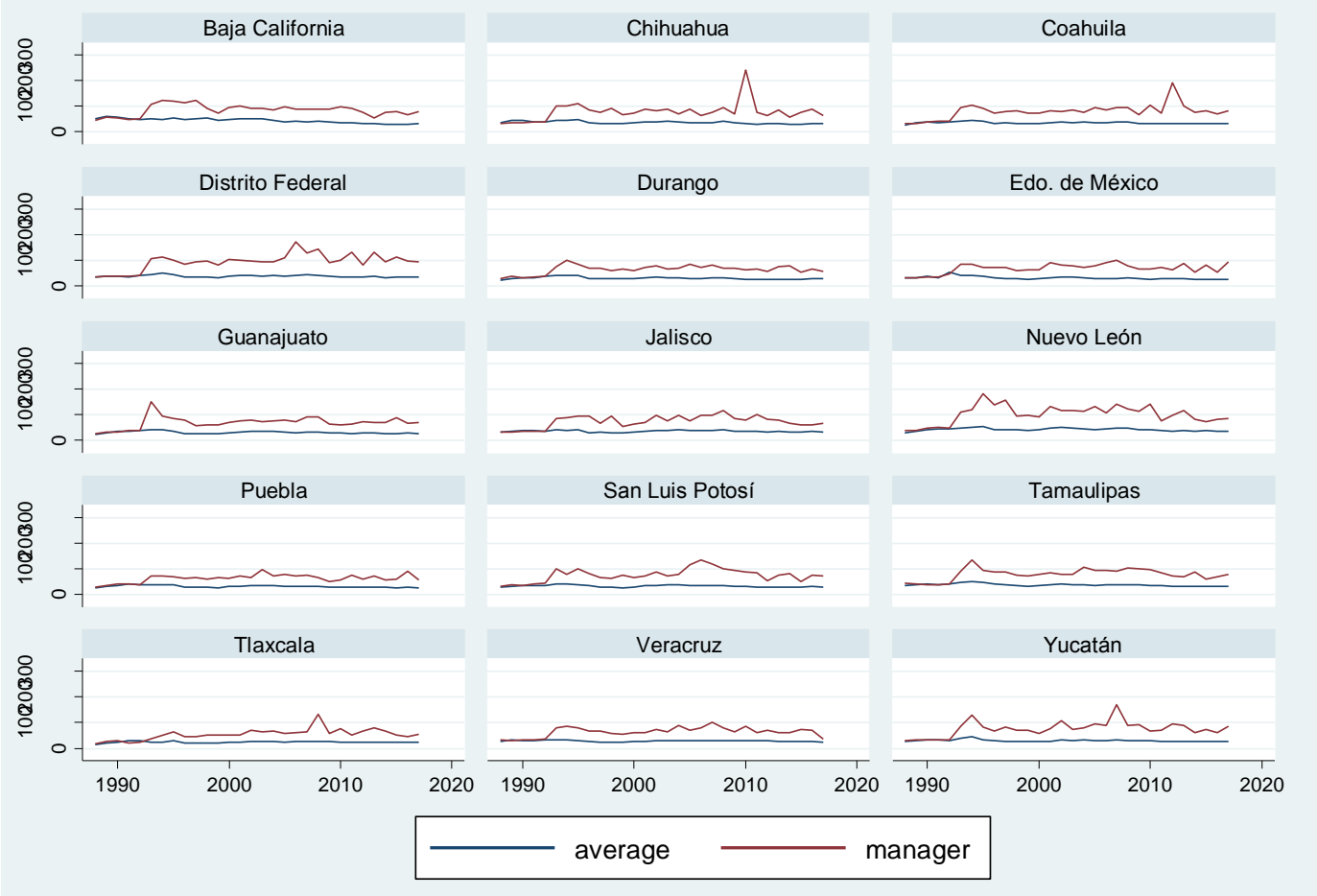

Source: Own elaboration with ENEU-ENOE data 1988-2017

According to the results obtained from the estimations, the variable for the percentage of people employed in the agricultural and services sectors has a strong effect on inequality. Graph 4 shows the proportion of people employed in each sector with respect to the working age population. 


\section{Graph 4. Proportion of people employed by sector}

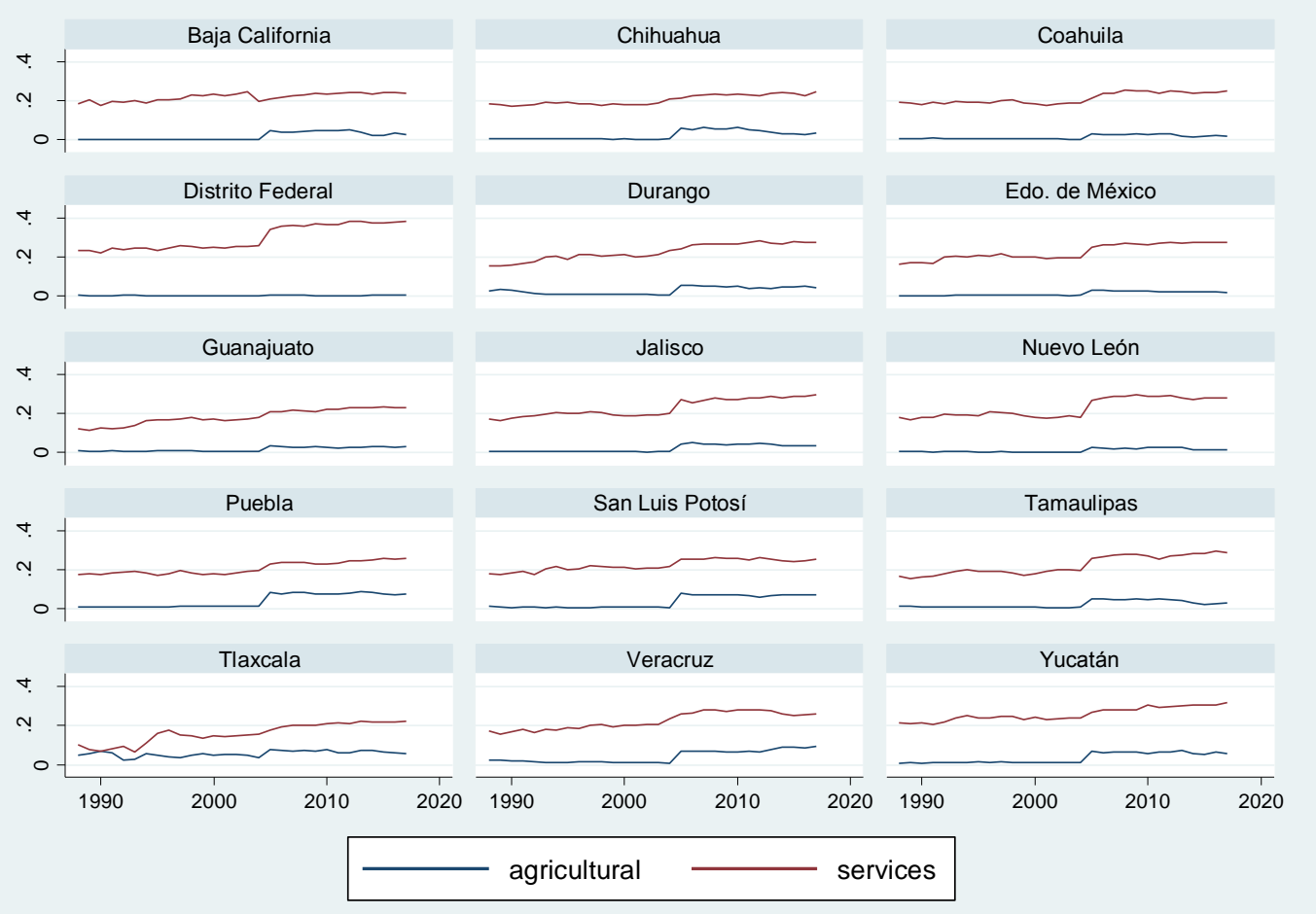

Source: Own elaboration with ENEU-ENOE data 1988-2017

It is observed that the entities that have had a greater growth in the proportion of people employed in the agricultural sector between 1994 and 2017 are Baja California and Puebla; and in the services sector this is found in Tlaxcala. In Graph 1 it had been found that these states presented prominent levels of inequality.

Finally, table 4 presents the results of the Phillips-Perron unit roots test in panel data.

\section{Table 4. Fisher test results}

\begin{tabular}{|l|r|r|}
\hline Method & Statistic & p-value \\
\hline Inverse of $X^{2}$ & 95.5153 & 0.0000 \\
\hline Inverse of Normal & -5.6245 & 0.0000 \\
\hline Inverse of logit t & -6.3378 & 0.0000 \\
\hline Inverse of modified $X^{2}$ & 8.4580 & 0.0000 \\
\hline
\end{tabular}

Source: Own elaboration with ENEU-ENOE data 1988-2017

The results indicate that in the four methods proposed by Choi (2001) the null hypothesis is rejected, that is to say, in these states the inequality variable has unit roots, therefore, it is concluded that at least on one state inequality is stationary, indicating that it is stable across time (the values of the series and its variability tend to oscillate around a constant mean). 


\section{Conclusions}

The results of the investigation show that the implementation of NAFTA directly impacts wage inequality. This means that from 1994 onwards, the wage gap increased between the richest and the poorest.

It was found that the proportion of workers in the services sector directly affects inequality, indicating that the relative wages payed in this sector are less than those payed in other sectors. The sectorial variable with the greatest impact on wage inequality was the one corresponding to the agricultural sector due to a decrease in labor supply that it presented, attributed to the loss of 1.3 million jobs in this sector from NAFTA onwards (Audley et al, 2003).

Although the manufacturing sector has had a relevant role in the Mexican economy after the implementation of NAFTA by attracting assemblers, factories, and new jobs, results indicate that the salaries obtained by this sector are irrelevant in terms of affecting wage inequality.

It was found that, in general, despite the obtained results in terms of wage from the implementation of NAFTA onwards, this economic integration has not diminished the wage differences as was expected; on the contrary, NAFTA has slightly increased the level of wage inequality of the Mexican people. Carlsen (2005) attributes this result to the fact that wages do not correspond to factors of the free market, but instead to other factors, which include: the political power of the labor sector, national and business policies, greater competition of China and Central America, and the lack of controls over transnational corporations. Other authors attribute the variations in inequality to fluctuations in the local labor markets and education supply (Meza $1999,2005)$, the production at a state and regional level (Messmacher, 2000), and the transfer of workers between productive sectors (Audley et al, 2003).

In 2017 the current government signed the initiative with draft decree to level the wages of workers to more equal terms. This law proposes the adjustment of minimum wages as a "recognition of the labor demands of the workers, who within their vulnerability have paid the cost of an erroneous policy of competitiveness based on low wages" (Iniciativa con proyecto de decreto para homologar los salarios y la movilidad de la fuerza laboral en la región del TLCAN, 2017).

\section{References}

ANTONCZYK, D.; FITZENBERG, B., and SOMMERFELD, K. (2010) Rising wage inequality, the decline of collective bargaining, and the gender wage gap. Labour economics, 17(5), 835-847. https://doi.org/10.1016/j.labeco.2010.04.008

AUDLEY, J.; PAPADEMETRIOU, D.; POLASKI, S. and VAUGHAN, S. (2003) La promesa y la realidad del TLCAN. Nueva York, Carnegie Endowment.

BLAU, F. and Kahn, L. (2017) The gender wage gap: Extent, trends, and explanations. Journal of Economic Literature, 55(3), 789-865. https://doi.org/10.1257/jel.20160995

BUNDRIA, S. And MORO-EGIDO, A. (2008) Education, educational mismatch, and wage inequality: Evidence for Spain. Economics of Education Review, 27(3), 332-341. https://doi.org/10.1016/j.econedurev.2006.10.005 
CAMPOS-VÁZQUEZ, R. (2013) Why did wage inequality decrease in Mexico after NAFTA?. Economía Mexicana: Nueva Época, 12(2), 245-278.

CAMPOS-VÁZQUEZ, R.; ESQUIVEL G. and LUSTIG, N. (2014) The rise and fall of income inequality in Mexico. 1989-2010. Falling inequality in Latin America: Policy changes and lessons, 140. https://doi.org/10.1093/acprof:oso/9780198701804.003.0007

CARD, D. (2001) The effect of unions on wage inequality in the US labor market. ILR Review, 54(2), 296315. https://doi.org/10.1177/001979390105400206

CARD, D. and DINARDO, J. (2002) Skill-biased technological change and rising wage inequality: Some problems and puzzles. Journal of labor economics, 20(4), 733-783. https://doi.org/10.1086/342055

CARLSEN, L. (2005) Balance del Tratado de Libre Comercio de América del Norte (TLCAN) en México: el mito de la convergencia. International Relations Center.

CASTRO, D. and HUESCA, L. (2007) Desigualdad salarial en México: una revisión. Papeles de población, 13(54), 225-264.

CHOI, I. (2001) Unit root tests for panel data. Journal of International Money and Finance. 20(2) 249-272. https://doi.org/10.1016/S0261-5606(00)00048-6

DOLTON, P.; O'NEILL, D.; and SWEETMAN, O. (1996) Gender differences in the changing labor market: the role of legislation and inequality in changing the wage gap for qualified workers in the United Kingdom. Journal of Human Resources, 549-565. https://doi.org/10.2307/146265

DUSTMANN, C., LUDSTECK, J., and SCHÖNBERG, U. (2009) Revisiting the German wage structure. The Quarterly Journal of Economics, 124(2), 843-881. https://doi.org/10.1162/qjec.2009.124.2.843

ELLIOT, L. (2016) Richest 62 people as wealthy as half of world's population, says Oxfam. The Guardian, 18.

ENEU. Documento metodológico de la Encuesta Nacional de Empleo Urbano (ENEU). INEGl: Publicaciones. Available in: http://www.beta.inegi.org.mx/app/biblioteca/ficha.html?upc=702825000017

ENOE. Cómo se hace la ENOE. Métodos y procedimientos. INEGI: Publicaciones. Available in: http://www.beta.inegi.org.mx/app/biblioteca/ficha.html?upc=702825006541

FREDERICK, S. (2016) The Standardized World Income Inequality Database. Social Science Quarterly, 97(5):1267-1281. https://doi.org/10.1111/ssqu.12295

INICIATIVA con proyecto de decreto para homologar los salarios y la movilidad de la fuerza laboral en la región del TLCAN, 2017. Available in: http://www.senado.gob.mx/sgsp/gaceta/63/2/2017-04-271/assets/ documentos/Inic Fuerza laboral TLCAN.pdf [Access 27 /02/2018]

ISLAM, S. and SAFAVI, M. (2019) Income Inequality and Labor Share in USA and Canada. Archives of Business Research, 6(12). https://doi.org/10.14738/abr.612.5927

JUHN, C., MURPHY, K. and PIERCE, B. (1993) Wage inequality and the rise in returns to skill. Journal of political Economy, 101(3), 410-442. https://doi.org/10.1086/261881 
KAHYALAR, N.; FETHI, S.; KATIRCIOGLU, S.; and Ouattara, B. (2018) Formal and informal sectors: is there any wage differential?. The Service Industries Journal, 1-35. https://doi.org/10.1080/02642069.2018.1482877

KATZ, L. (1999) Changes in the wage structure and earnings inequality. In Handbook of labor economics (Vol. 3, pp. 1463-1555). Elsevier. https://doi.org/10.1016/S1573-4463(99)03007-2

KILIC, R. (2002) Absolute and comparative advantage: Ricardian Model. Michigan State University, East Lansing, MI, 48824.

KRSTIC, G., and Sanfey, P. (2011) Earnings inequality and the informal economy. Economics of transition, 19(1), 179-199. https://doi.org/10.1111/j.1468-0351.2010.00400.x

KRUEGER, A. (1993) How computers have changed the wage structure: evidence from microdata, 19841989. The Quarterly Journal of Economics, 108(1), 33-60. https://doi.org/10.2307/2118494

LEMIEUX, T. (2006) Increasing residual wage inequality: Composition effects, noisy data, or rising demand for skill?. American Economic Review, 96(3), 461-498. https://doi.org/10.1257/aer.96.3.461

MADDALA, G. and WU, S. (1999) A comparative study of unit root tests with panel data and a new simple test. Oxford Bulletin of Economics and Statistics. 61: 631-652. https://doi.org/10.1111/1468$0084.61 . s 1.13$

MARCOUILLER, D.; DE CASTILLA, V. and WOODRUFF, C. (1997) Formal measures of the informalsector wage gap in Mexico, El Salvador, and Peru. Economic development and cultural change, 45(2), 367-392. https://doi.org/10.1086/452278

MESSMACHER, M. (2000). Desigualdad Regional en México, el Efecto del TLCAN y Otras Reformas Estructurales. Documento de investigación, 4, 33. Available in: http://www.banxico.org.mx/publicaciones-y-discursos/publicaciones/documentos-deinvestigacion/banxico/\%7BB00EB2B3-9814-A920-F717-98B736569875\%7D.pdf

MEZA, L. (1999) Cambios en la estructura salarial de México en el periodo 1988-1993 y el aumento en el rendimiento de la educación superior. El Trimestre Económico, 66(2), 189-226.

MEZA, L. (2005) Mercados laborales locales y desigualdad salarial en México. El Trimestre Económico, 62(285), 133-178.

SALAI-I-MARTIN, X. (2006) The world distribution of income: falling poverty and... convergence, period. The Quarterly Journal of Economics, 121(2), 351-397. https://doi.org/10.1162/qjec.2006.121.2.351

TANSEL, A. and BODUR, F. (2012) Wage inequality and returns to education in Turkey: A quantile regression analysis. Review of Development Economics, 16(1), 107-121. https://doi.org/10.1111/j.1467-9361.2011.00655.x

TODARO, M. and SMITH, S. (2012) Economic Development, 11th Edition. Addison-Wesley/Pearson.

WEICHSELBAUMER, D. and WINTER-EBMER, R. (2005) A meta-analysis of the international gender wage gap. Journal of Economic Surveys, 19(3), 479-511. https://doi.org/10.1111/j.09500804.2005.00256.x 
YANG, T. AND Cao, Z. (2019) Why China's Gini Coefficient Has Been Falling?. In A New Era (pp. 59-82). Palgrave Macmillan, Singapore. https://doi.org/10.1007/978-981-10-8357-0_3 